Institute for Research on Poverty

Discussion Paper no. 1119-97

\title{
Why Do Small Establishments Hire Fewer Blacks than Large Ones?
}

\author{
Harry J. Holzer \\ Department of Economics \\ Michigan State University \\ E-mail address: holzer@pilot.msu.edu
}

January 1997

I thank John Bound and David Neumark for helpful comments, Jess Reaser for computational assistance, and the Rockefeller Foundation for financial assistance.

IRP publications (discussion papers, special reports, and the newsletter Focus) are now available electronically. The IRP Web Site can be accessed at the following address: http://www.ssc.wisc.edu/irp/ 


\begin{abstract}
This paper shows that small establishments are much less likely to hire and employ blacks than are larger establishments. A number of possible explanations for this result are considered, such as differences across establishments in application rates from blacks, skill needs, locations, and recruiting behavior. Although these factors can account for some of the differences between small and large employers, much remains unexplained. The results suggest that discrimination in hiring may be much more pervasive at smaller establishments than larger ones.
\end{abstract}




\section{Why Do Small Establishments Hire Fewer Blacks than Large Ones?}

It is well-known that some establishments are more likely to hire blacks (or other minorities) than others. For instance, federal contractors are more likely to hire blacks than noncontractors, due to federal Affirmative Action regulations (Leonard 1990). Also, firms located in central cities or closer to the residential locations of blacks are more likely to hire them than are those located further away (Kain 1968; Holzer and Ihlanfeldt 1996b).

This paper documents a strong empirical relationship that has received much less attention in the literature to date: namely, that small establishments hire many fewer blacks (as percentages of their employees) than do large establishments. This finding has recently been noted elsewhere by Carrington, McCue, and Pierce (1995) and Chay (1995) and is implicit in earlier work by Smith and Welch (1984). ${ }^{1}$ But the link between establishment size and black employment has never been systematically explored with microlevel establishment data; thus, the magnitude of this relationship has not been well established, and its underlying causes are not well understood.

The paper briefly discusses some possible reasons for a relationship between employer size and the hiring of blacks. I then describe the data used here, which are from a new survey of employers in several large metropolitan areas in the United States. Some summary results on the relationship between establishment size and the employment of blacks are presented, followed by results from some regressions that test a variety of hypotheses that might explain the relationship. Since our ability to account for this

${ }^{1}$ Both Carrington, McCue, and Pierce and Chay analyze changes over time in the relationship between establishment size and tendency to hire blacks. Carrington et al. stress that this relationship grew much more positive during the late 1960s and early 1970s, and they infer from this that the 1964 Civil Rights Act was responsible for this development. Smith and Welch make a similar point in their comparison of black employment at firms that are required to file EEO-1 firms with the federal government compared with those that are not, a distinction that is based almost exclusively on establishment size (as noted below). Chay notes the improvement of black employment and relative earnings in smaller establishments in the South after the Equal Employment Opportunity Act was passed in 1972, but a growing gap between black employment shares at small and large firms (especially in the South) can clearly be found in his data. 
relationship is limited, the conclusion discusses other possible explanations, such as a greater pervasiveness of discrimination at smaller establishments.

\section{ESTABLISHMENT SIZE AND EMPLOYEE RACE}

Why might smaller establishments hire fewer blacks than larger ones? At least a priori, one might expect the opposite. Becker's model (1971) implies that firms with product market power are more likely to discriminate than are competitive firms; if such market power is positively correlated with establishment size, we might expect more hiring discrimination against blacks at larger establishments. ${ }^{2}$

Large establishments also employ more highly skilled workers, train them more intensively, and pay them higher wages and benefits than do small establishments (Garen 1985; Barron, Bishop, and Lowenstein 1987; Brown and Medoff 1989; Brown, Hamilton, and Medoff 1990; Lynch and Black 1995). ${ }^{3}$ Since on average whites have higher education levels and cognitive skills (at least as measured by test scores) than do blacks (e.g., Neal and Johnson 1996), one might expect larger establishments to hire more whites for these reasons as well. ${ }^{4}$ Finally, note that larger establishments have lower turnover, job vacancy, and gross hire rates (Anderson and Meyer 1994; Holzer 1994, 1996); and they receive more applicants per opening than do smaller establishments (Holzer, Katz, and Krueger 1991). ${ }^{5}$ The greater pressure to hire

\footnotetext{
${ }^{2} \mathrm{Of}$ course, it is also possible that larger establishments will engage inreverse discrimination against whites, which is discussed below.

${ }^{3}$ Brown and Medoff (1989) show that the higher skill levels of employees at large establishments only partly accounts for their higher wages there. Garen (1985) and Barron, Bishop, and Lowenstein (1987)argue that monitoring difficulties in large establishments lead them to substitute skilled for unskilled employees, leading also to higher training and wages.

${ }^{4}$ Neal and Johnson (1996) show that the higher educational attainment and test scores of whites account for much of the black-white wage gap and less of the gap in employment rates.

${ }^{5}$ The lower turnover rates and higher application rates associated with size are only partly explained by higher wages in these studies. But the differences in turnover rates mostly account for differences ingross hire rates across the firms; whether differences also exist in net hire rates by size are less clear (Davis, Haltiwanger, and Schuh 1995).
} 
more frequently from a smaller applicant pool might thus also lead smaller establishments to hire relatively less-skilled employees and therefore more blacks.

On the other hand, larger establishments might receive more applications from blacks, perhaps because of their geographic locations, industries, or greater tendency to be unionized. ${ }^{6}$ Larger establishments might also hire more employees from among their black applicants, due to greater pressure (real or perceived) from black customers and the government, through its Equal Employment Opportunity (EEO) and Affirmative Action activities. Differences in their personnel practices and hiring behavior might lead to similar results. ${ }^{7}$

\section{DATA AND SUMMARY FINDINGS}

The data used to test these notions are drawn from a new survey of employers that was administered between June 1992 and May 1994 to over 3,000 employers in four large metropolitan areas: Atlanta, Boston, Detroit, and Los Angeles. The survey was administered over the phone to individuals responsible for hiring, and focused on employer skill needs, recruiting behavior, and the characteristics of employees hired and jobs filled.

The sample of firms surveyed was drawn from two sources: roughly 30 percent of the sample was generated by employees who were respondents in a household survey in the same four metropolitan areas,

${ }^{6}$ For evidence that blacks have traditionally been more heavily represented and have earned relatively higher wages in the union sector, see Freeman and Medoff (1984). Blacks have also traditionally been relatively concentrated in manufacturing jobs in some areas, such as the Midwest, but today they are more heavily represented in the services (Bound and Holzer 1993; Holzer 1996). The relatively greater concentration of larger establishments in central cities is also noted in Holzer (1996).

${ }^{7}$ For instance, smaller firms might rely more heavily on less costly informal recruitment procedures and subjective screening devices such as interviews, which might create relatively greater disadvantages for black job seekers (e.g., Holzer 1987; Moss and Tilly 1995). The use of more formal hiring mechanisms among larger firms might also reflect their concerns over EEO. The notion that employer discrimination might be related to the preferences of its customers was first noted in Becker (1971), and receives support, especially for jobs involving direct contact with customers, in Holzer and Ihlanfeldt (1996a). 
and the rest were generated by lists provided by Survey Sampling Inc. (SSI). ${ }^{8}$ The latter sample was stratified ex ante by establishment size, drawn to reflect the distribution of workers across establishment sizes in the labor force, while the former sample implicitly reflects this distribution. Both samples are therefore already weighted by employee size, and we can analyze either individual jobs (such as the one most recently filled) at these firms or employment overall. ${ }^{9}$ Furthermore, response rates to the survey among firms that passed the screening averaged 67 percent, and I have found little evidence of selection bias induced by nonrandom response patterns in the data. ${ }^{10}$

Table 1 presents summary data on the fractions of employees who are black (as reported by the survey respondent) at all establishments and in the following five categories based on numbers of employees: $1-14,15-49,50-99,100-499$, and 500 or more. ${ }^{11}$ These categories coincide with those that determine establishment coverage by EEO laws (since those with 15 or more employees are covered while those with fewer than 15 are not) and federal monitoring of their hiring practices (since all establishments with 100 or more employees and some with 50-99 are required to file EEO-1 forms, which are used by the government to monitor EEO performance, while the remainder are not). The variables measuring the hiring of blacks include the probability that the last worker hired into the firm is

${ }^{8}$ For analysis of data from another survey of firms drawn from SSI samples see Barron, Berger, and Black (1994). The household and employer surveys in the four metropolitan areas are part of the Multi-City Study of Urban Inequality supported by the Ford and Russell Sage Foundations.

${ }^{9}$ Sample weights are still necessary when analyzing summary data, to adjust for the deliberate underrepresentation of jobs requiring college in the sample as well as for various characteristics of the household samples that generated some of the firms.

${ }^{10}$ Since SSI provided data on industry, location, and establishment size for all firms, I could test for differences in response rates across these observable dimensions. I found only small and/or insignificant differences in most cases. The distributions of establishments across industries and size categories are quite comparable to those found in County Business Patterns data in the same areas.

${ }^{11}$ The median establishment size is just under 50. The smallest size category contains 27 percent of the total sample, while the other categories each contain 12-23 percent. 
TABLE 1

Black Applicants and Employment, by Establishment Size

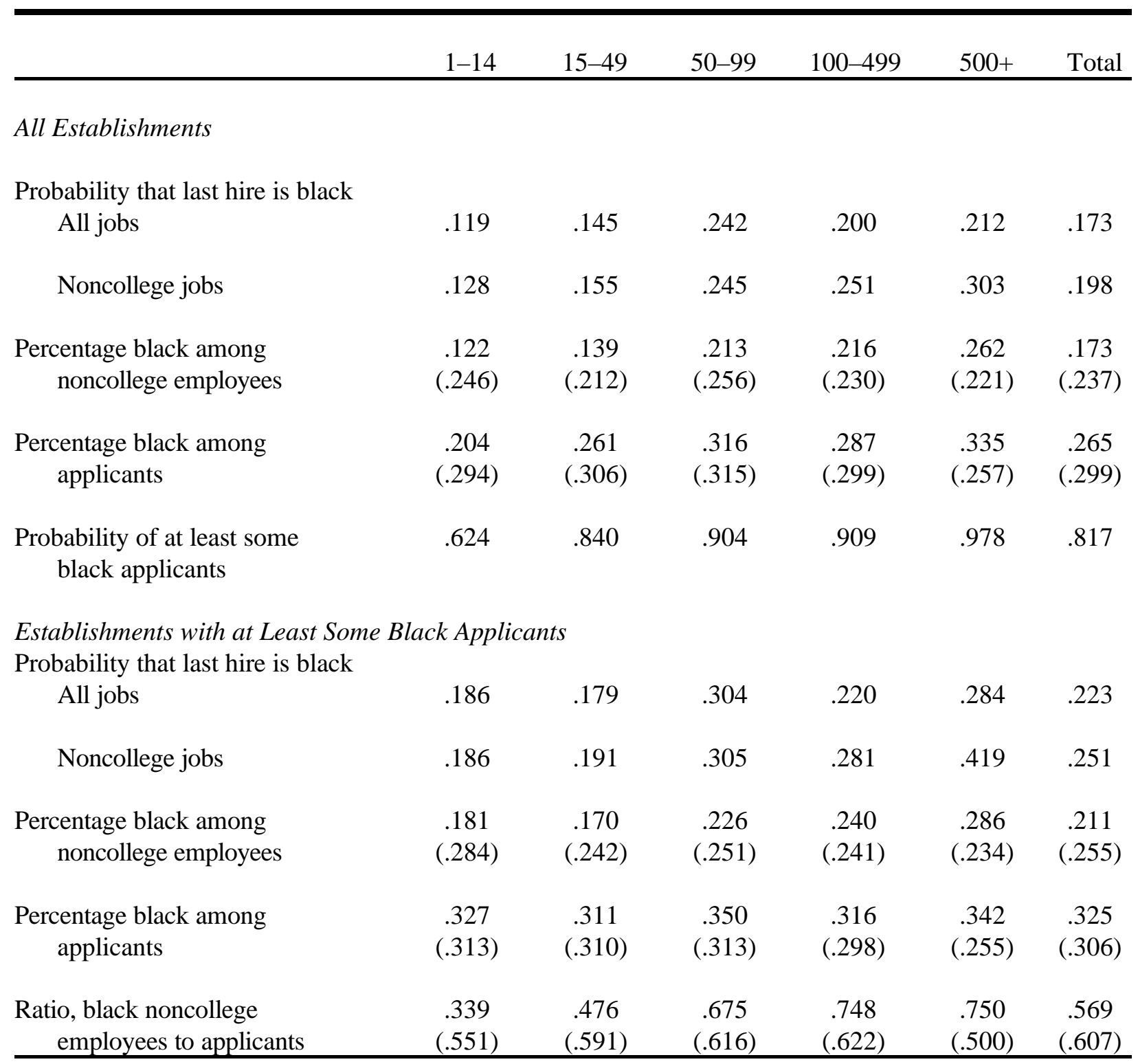

Note: All results are sample-weighted; standard deviations appear in parentheses below means of continuous variables. The ratio of black noncollege employees to applicants is the mean of ratios computed for individual establishments. 
black, both for all jobs and for those that do not require college degrees, as well as the percentage black among all noncollege employees at the establishment. ${ }^{12}$

Since the distribution of blacks across establishments can clearly be driven by the choices of workers as well as employers, data on the racial composition of applicants across firms are also presented. Thus, data are presented on the percentage of all applicants to the establishment who are black and the percentage of firms for which this figure is nonzero. Most of these data, and the ratio of black employees to applicants, for establishments that receive at least some applications from blacks are also included. All means are sample-weighted.

The results show a very striking tendency for the percentages of new hires and overall employment accounted for by blacks to rise with establishment size. This pattern is particularly pronounced among employees in positions that do not require college degrees, where the percentage of blacks in the largest establishment size category (i.e., about 30 percent) is more than twice as large as that in the smallest category (about 13 percent). This latter positive relationship is monotonic, and can be found even among the categories of firms whose employment practices are subject to EEO law (those with 15 or more workers) as well as those routinely monitored by the federal government (those with 100 or more employees).

The data indicate that the smallest establishments hire considerably smaller percentages of blacks than found in the populations of these four metropolitan areas, while the largest hire somewhat more. ${ }^{13}$ These differences by establishment size are also somewhat larger than those implied by Carrington,

\footnotetext{
${ }^{12}$ The most recently filled job is more likely to reflect those within the firm that experience higher turnover or recent net employment growth. But occupational and racial distributions across these two variables do not differ very much from each other or from the distributions reported in the 1990 Census of Population for the relevant metro areas (Holzer 1996).

${ }^{13}$ Blacks constitute an (unweighted) average of roughly 17 percent of the total populations in these four metropolitan areas and 19 percent of the noncollege graduate populations. Hispanics and Asians together constitute an additional 16 percent of the populations, primarily due to their heavy concentrations in Los Angeles. Eliminating them from the sample does not change the overall pattern of racial employment across size categories.
} 
McCue, and Pierce and by Chay; this could reflect differences across our studies in the geographic areas considered (mine focuses only on four large metro areas) or the relatively more aggregated data used in the other papers. ${ }^{14}$ On the other hand, the magnitudes are quite consistent with those found in nationwide data by Smith and Welch. ${ }^{15}$

I also find some tendency for small establishments to receive fewer black applicants than larger ones. This is primarily caused by a greater tendency of larger establishments to receive a nonzero percentage of their applications from blacks-about 38 percent of the smallest firms receive no applications from blacks, whereas virtually all the largest firms receive at least some. ${ }^{16}$ But, conditional on receiving at least some black applicants, the percentage of blacks among applicants does not rise with establishment size while the percentage employed does rise.

Therefore, it is clear that the ratio of black employees to applicants (among firms receiving at least some of the latter) is substantially smaller among firms in the lowest size category than in the largest. ${ }^{17}$

\footnotetext{
${ }^{14}$ Chay (1995) finds differences of 2-3 percentage points in the shares of employment accounted for by blacks between sectors with high and low fractions of small establishments, while Carrington, McCue, and Pierce (1995) find roughly comparable differences between white and black males (and somewhat larger ones between females) in the probabilities of employment in the smallest establishment size category. Both of these other papers primarily analyze racial employment differences across states by 2-digit industry cells over time, where the latter are then linked to measures of establishment size. Thus, within-cell variation in racial employment patterns across establishments is not captured. Chay also presents some distributions of white and black males across establishment size categories as reported by employees in the 1979 CPS, which show fairly substantial racial differences in employment patterns outside of the South. I find little variation by gender or by metropolitan area in racial employment patterns across size categories.

${ }^{15}$ They find that the percentage of employees who are black in firms that file EEO-1 forms is roughly 12 percent, while it is under 6 percent for those not required to file; the spread among females is even larger than among males. Comparing establishments with 75 or more employees in my data to those with fewer than 75 (since some firms with 50-99 employees are required to file and some are not), I find that the percentages of employees who are black are 21 percent and 14 percent, respectively.

${ }^{16}$ The tendency for some small firms to receive no black applicants might reflect their tendency to receive a small number of applicants overall, the low fraction of blacks in the population, and the indivisibility of each application. For example, since only about 20 percent of the population in these areas is black, the above factors alone could account for an absence of black applicants in firms receiving fewer than five applications over extended periods of time.

${ }^{17}$ The ratios presented in the table are the means of ratios of black employees to applicants computed separately for each individual establishment, rather than the ratios of means in earlier rows. The latter tend to put somewhat greater weight on larger firms than do the former; and since the sample is already size-weighted, there is
} 
Indeed, the bottom row of Table 1 indicates that the smallest establishments hire only about a third as many blacks as they receive applications from, while the largest establishments hire over three-quarters as many. ${ }^{18}$

That all of these ratios are below one indicates a relative disinclination to hire black applicants in all of these establishment categories, perhaps due to the applicants' lower relative skills or employer discrimination. But the differences in hiring ratios across size categories clearly indicate a relatively greater inclination among the larger firms to hire their black applicants, at least given the characteristics of black and other applicants. Furthermore, applicant flows from particular groups may well be endogenous to the likelihood that group members will be hired, and will also depend on recruitment practices that reflect the employer's preferences. These factors will cause ratios of hires to applicants to be generally biased toward one, and the differences in ratios across establishment size categories will likely understate the true racial differences in hiring across these firms. ${ }^{19}$

One possible reason for the relationships between establishment size and black applicant or employment rates is that larger establishments are more likely to be located closer geographically to where blacks live. ${ }^{20}$ As a first cut at this issue, Table 2 presents some of the above data separately for

little need to do so. However, the positive relationship between employment ratios and establishment size can be found with either method of computation. Establishment-level ratios can only be computed for employees rather than new hires, since the race of the latter is a dichotomous (and job-specific) variable. I also omit a very small number of outlier observations in which the computed ratio is above 3 (presumably because of reporting errors in one or both underlying variables).

${ }^{18} \mathrm{An}$ average of such ratios across different ethnic groups, weighted by the percentage of applicants accounted for by each group, should sum to one.

${ }^{19}$ It is possible that larger firms receive black applicants of higherquality, relative to their white applicants, though it is not clear why this might be the case.

${ }^{20}$ Proximity to black residences should clearly affect the flow of black applicants to any firm; it might also affect the firm's relative tendency to hire from among those applicants, as discriminatory employers may choose to locate further away from these residences (Bloch 1994). 
TABLE 2

Black Applicants and Employment by Establishment Size:

Central Cities Compared with Suburbs

1-14

15-49

$50-99$

$100-499$

$500+$

Total

\section{Central City}

Percentage black among noncollege employees

.268

.247

.399

.319

.427

.306

Percentage black among applicants

.296

.406

.457

.329

.494

.372

Ratio, black noncollege employees to applicants

.473

.550

.712

.934

.906

.684

Suburbs

Percentage black among noncollege employees

.072

.088

.122

.153

.177

.109

Percentage black among applicants

.164

.188

.206

.251

.255

.203

Ratio, black noncollege employees to applicants

.278

.417

.625

.722

.623

.512

Note: "Central city" refers to the cities of Atlanta, Boston, Detroit, and Los Angeles; "suburbs" refer to all noncentral city municipalities with fewer than 30 percent blacks among residents. The ratio of employees to applicants is computed only for establishments with some black applicants. 
firms that are located in the primary central cities of these metropolitan areas as opposed to those located in the predominantly white suburbs. ${ }^{21}$

The results clearly show that firms located in the central cities receive more black applicants and also hire more black employees, even relative to the numbers of applicants they receive. Within each establishment size category, the ratio of black employment to applicants is $10-30$ percentage points higher among central-city than suburban firms. Since the skills of black applicants relative to those of whites are likely to be higher at suburban establishments than at those in the central cities, the data suggest greater employer preferences for (or less discrimination against) blacks in the central cities. ${ }^{22}$

On the other hand, the relationship between establishment size and the ratio of black employees to applicants holds within both areas. The smallest establishments in the suburbs hire only 28 percent as many blacks as appear in their applicant pools, while these percentages for the largest establishments are 62-72 percent. Comparable numbers for central-city firms are 47 percent and over 90 percent. Thus, geographic location does not seem to account for the tendency of larger establishments to hire more blacks.

\section{REGRESSION ESTIMATES}

Table 3 presents results from regressions in which black employment outcomes are the dependent variables, and dummies for establishment size, along with a variety of controls, are the independent variables. There is one set of estimates in which the dependent variable is the percentage of

${ }^{211 " C e n t r a l ~ c i t i e s " ~ h e r e ~ r e f e r s ~ o n l y ~ t o ~ t h e ~ p r i m a r y ~ c e n t r a l ~ c i t i e s ~ o f ~ e a c h ~ m e t r o p o l i t a n ~ a r e a-i . e ., ~ t h e ~ c i t y ~ o f ~}$ Atlanta, the city of Boston, etc. The suburban category excludes smaller central cities in each metropolitan area (such as Marietta in the Atlanta metro area, Pontiac and Dearborn in the Detroit metro area, etc.) as well as municipalities whose residents are at least 30 percent black.

${ }^{22}$ See Holzer (1996). Education levels are generally higher among blacks who live in the suburbs than among those in the central cities, while the opposite appears to be true for whites. Thus, relative skill levels for black applicants are likely higher at firms located in the suburbs. 
TABLE 3

Estimated Effects of Establishment Size on Black Employment

$1-14 \quad 15-49 \quad 50-99 \quad 100-499 \quad \mathrm{R}^{2} /-\log \mathrm{L}$

Percentage black among

noncollege employees

1. Includes MSA and

year dummies only

$\begin{array}{llll}-.116 & -.092 & -.053 & .013 \\ (.023) & (.023) & (.025) & (.023) \\ & & & \\ -.051 & -.052 & -.029 & .029 \\ (.018) & (.018) & (.019) & (.018)\end{array}$

.215

2. Adds percent

black applicants

$\begin{array}{lllll}-.039 & -.038 & -.007 & .042 & .542 \\ (.017) & (.017) & (.019) & (.016) & \\ & & & & \\ -.048 & -.039 & -.017 & .043 & .572 \\ (.018) & (.017) & (.018) & (.017) & \end{array}$

previous "validation" efforts

5. Adds applicants per opening; and

$\begin{array}{llll}-.052 & -.041 & -.019 & .042 \\ (.018) & (.018) & (.018) & (.017)\end{array}$

new hire and vacancy rates

Probability that last hire is black,

noncollege jobs

1. Includes MSA and

year dummies only

$\begin{array}{rrrrr}-1.192 & -.752 & -.366 & -.200 & 562.6 \\ (.290) & (.280) & (.302) & (.263) & \\ {[-.202]} & {[-.127]} & {[-.062]} & {[-.034]} & \end{array}$

2. Adds percent

black applicants

$\begin{array}{ccccc}-.944 & -.628 & -.253 & -.157 & 467.1 \\ (.323) & (.312) & (.337) & (.291) & \\ {[-.160]} & {[-.106]} & {[-.043]} & {[-.027]} & \end{array}$

3. Adds industry, location,

$\begin{array}{ccccc}-.969 & -.673 & -.111 & -.078 & 450.7 \\ (.340) & (.326) & (.343) & (.301) & \\ {[-.164]} & {[-.114]} & {[-.019]} & {[-.013]} & \end{array}$

4. Adds percent black customers,

$\begin{array}{rcccc}-1.138 & -.747 & -.213 & -.051 & 435.5 \\ (.379) & (.351) & (.361) & (.317) & \\ {[-.192]} & {[-.126]} & {[-.036]} & {[-.009]} & \\ & & & & \\ -1.146 & -.750 & -.224 & -.050 & 434.6 \\ (.387) & (.356) & (.367) & (.318) & \\ {[-.194]} & {[-.127]} & {[-.038]} & {[-.008]} & \end{array}$

5. Adds applicants per opening, and new hire and vacancy rates use of Affirmative Action, and previous "validation" efforts

$-1.138$$$
\text { [..192] }
$$$$
\text { (351) }
$$$$
[-.126]
$$

(361)

$(317)$

$[-.009]$

$[-.008]$

(table continues) 
TABLE 3, continued

\begin{tabular}{llcccc}
\hline & & & & & \\
& $1-14$ & $15-49$ & $50-99$ & $100-499$ & $\mathrm{R}^{2} /-\log \mathrm{L}$ \\
\hline & & & & & \\
6. Adds starting wage, skill & -1.125 & -.706 & -.341 & -.100 & 415.1 \\
$\quad \begin{array}{l}\text { requirements, screening methods, } \\
\text { and hours of formal training }\end{array}$ & $(.395)$ & $(.374)$ & $(.400)$ & $(.325)$ & \\
\hline.- .190$]$ & {$[-.119]$} & {$[-.058]$} & {$[-.017]$} & \\
\hline
\end{tabular}

Note: Sample size for the top 5 rows is 1458 , while for the bottom 6 rows it is 1238 . The first set of equations is estimated using OLS, while the second set is estimated using logit. Huber-White standard errors are in parentheses, and partial derivatives (computed at sample means) appear in brackets under logit estimates. 
blacks among all noncollege employees (estimated from OLS equations), and another set in which the dependent variable is the probability that the last worker hired in a noncollege job is black (estimated from binomial logit equations). ${ }^{23}$

Results from a variety of specifications are presented for each set of equations, corresponding as closely as possible to the factors (listed in Section 1) that might account for the relationship between establishment size and employee race. The first equation begins with controls only for the metropolitan area and the year of the survey; then controls for the fraction of blacks among applicants to the establishment are added in the second equation; industry dummies, the percentage of workers covered by collective bargaining, and a variety of locational variables in the third equation; controls for several race-related factors, such as whether or not Affirmative Action is used in recruiting or hiring, whether or not the firm has ever had to "validate" its hiring rules (i.e., relate them to worker performance on the job), and the percentage of establishment customers who are black in the fourth equation; and numbers of applicants per opening, the gross hire rate, and the current vacancy rate in the fifth equation. ${ }^{24}$

For the equations in which the dependent variable is for the last job filled, several job-specific variables were added in a sixth specification. These include the log of the starting wage on the job, and a variety of dummy variables for daily task performance, hiring requirements, and recruitment or screening

\footnotetext{
${ }^{23}$ Standard errors have been corrected for heteroscedasticity using Huber-White methods. Despite the limited dependent variables used in the first set of regressions, I present results from OLS rather than Tobit estimators due to the likelihood that errors are non-normal; but results estimated for the latter do not differ qualitatively from those of the former.

${ }^{24}$ Virtually all of these variables are described at greater length in Holzer (1996). The locational variables (in addition to location in central city, suburb, or other location) include whether the establishment is located within one-fourth of a mile from public transit; and relative distances to the black and white populations in the metro area, based on a weighted average of the distance from each establishment's census tract to all other census tracts in the metro area, weighted by fractions of white and black populations in each tract (see Holzer and Ihlanfeldt 1996a). The gross (or new) hiring rate as a percentage of current employment is measured for the previous year; applicant flows (normalized for the duration of hiring) refer to the most recently filled job; and the vacancy rate is defined as the current number of vacant jobs out of the total number (filled or vacant). The gross hiring rate across firms is highly correlated with the turnover rate (at roughly .7), so both were not included. If firms reported receiving more than 200 applicants per week or hiring more than 5 times the number of currently employed workers (which each occurred in 1-2 percent of all cases), the values of these variables were assigned these upper limits.
} 
methods used in filling the position. ${ }^{25}$ The total hours of formal training provided to those hired into these jobs is included as well.

Thus, virtually all of the differences in labor market practices between small and large firms that have been documented in the literature and discussed above as possible determinants of the hiring of blacks are at least represented among the controls, though these are no doubt incomplete. ${ }^{26}$ The implications of such unobserved heterogeneity for interpreting the effect of establishment size on the hiring of blacks is discussed more fully below.

In any event, the means on these independent variables (except for race of applicant and time or metro area dummies) by establishment-size categories appear in Appendix Table A.1. As expected, smaller establishments are less likely to have collective bargaining; they are more likely to be in the retail trade and construction industries, and somewhat less likely to be in manufacturing, the services, and the public sector; they are less likely to be located in central cities, near public transit, and near black residential areas; they are less likely to use Affirmative Action and to have black customers; and they are more likely to use informal recruitment methods. All of these characteristics likely contribute to their lower tendency to hire blacks. On the other hand, small firms pay lower wages, receive fewer applicants, and have higher vacancy and new hire rates; these characteristics might well imply the opposite effects for black employment. $^{27}$

\footnotetext{
${ }^{25}$ Daily task performance variables measure contact with customers, reading/writing of paragraphs, use of arithmetic, and use of computers. Other hiring requirements include high school diplomas, specific experience, or previous vocational training. Recruitment dummies are for informal referrals (from current employees or others), newspapers, walk-ins (or help-wanted signs), and private agencies, with public/community agencies and schools as the omitted category. Screening variables include use of non-drug tests and probation periods. For more detail on all of these variables see Holzer (1996).

${ }^{26}$ Many of the underlying determinants of these labor market practices, such as capital-labor ratios or product market rents, are not measured here. On the other hand, the wage differentials and other differences in hiring across size establishment appear to be largely independent of these factors (Brown and Medoff 1985).

${ }^{27}$ Most of the above differences are significant at the .10 level. Also note that some skill needs (e.g., daily reading/writing and use of computers, high school diploma requirements) are lower among smaller establishments, while others (e.g., use of arithmetic and customer contact) are actually higher.
} 
Regarding the coefficients and standard errors on the control variables, many have the anticipated effects on the hiring of blacks. ${ }^{28}$ For instance, locational variables (such as distance of the establishment from public transit and from black populations) generally have significant effects in the anticipated directions; the presence of black customers and applicants have significant positive effects, as do gross hire rates and vacancy rates; and most recruiting mechanisms (especially informal referrals) have negative effects relative to the use of public agencies, as do certain skill requirements (such as daily use of arithmetic and previous specific experience).

But the results of the regression analysis in Table 3 also suggest that most of these controls account for relatively small parts of the effects of establishment size on the hiring of blacks. In particular, controlling for the percentage of applicants who are black reduces the size effects by half or more in the equations for percentage black among employees, and by somewhat less in the equations for the last hired worker. ${ }^{29}$ Controlling for industry, location, and presence of collective bargaining further reduces the size effects in the percent black equations by relatively small amounts.

On the other hand, controlling for the overall size of applicant flows and the rates of turnover and vacancies, as well as the race of customers and Affirmative Action/validation, does little to reduce the magnitudes of size effects in either equation. Indeed, the size effects become a bit larger in some cases. The same is true for controls for job-specific characteristics such as wages, skill needs, recruiting, and screening patterns. ${ }^{30}$ Thus, much of the relationship between establishment size and race of employees remains even after controlling for all of these observable characteristics. ${ }^{31}$

\footnotetext{
${ }^{28}$ Many of these results also appear in Holzer (1996) and Holzer and Ihlanfeldt (1996b). A table containing these results is available upon request from the author.

${ }^{29}$ Since the applicant variable is firm-wide, one would expect its explanatory power to be somewhat weaker in explaining job-specific hiring patterns.

${ }^{30} \mathrm{~A}$ comparable set of estimated equations in which the dependent variable is theratio of employees to applicants generally yield very similar results.

${ }^{31}$ The size effects are generally smaller, especially after including controls, in the equations for percentage black than in those for the probability that the last hire is black. This was also true, but to a lesser extent, in Table
} 
Before concluding, we note that if smaller establishments hired black applicants in the same proportions as do larger ones, there would be very substantial increases in the demand for labor facing blacks, and consequently in their employment and earnings. ${ }^{32}$ We note that the relatively greater concentration of blacks than whites in larger establishments contributes to their current relative wages; with comparable distributions across establishment sizes, the relative wages of employed blacks would be a bit lower. ${ }^{33}$ But the overall net effect of such a shift in the demand for blacks among small establishments would likely lead to significantly higher wages and employment of blacks overall.

\section{DISCUSSION}

The results presented above show that small establishments hire much smaller percentages of black employees than do larger establishments. They also hire much smaller percentages of their black applicant pools. While establishment characteristics such as industry, location, and the presence of blacks in the customer pool can account for small parts of these estimated effects, much remains unexplained.

Differences in the wage levels and skill needs of establishments, their gross hire and vacancy rates, as well as their different recruiting and screening activities, also do little to help account for the observed difference in racial hiring outcomes across establishment size categories.

One of the limitations of this study is its reliance on a single cross section of establishments in estimating these effects. Clearly, unobserved heterogeneity across jobs and establishments could somehow

1. The sample-weighting that was used in Table 1 but not Table 3 thus accounts for some of the difference in results across the two sets of equations, though not all of it.

${ }^{32}$ Weighted averages of the lowest estimated differentials in Table 3 (weighted by fractions of the workforce in each size category) yield employment effects of .07-.10, which (relative to the means of the current probabilities of employing blacks) imply that the demand for black labor would be 40-50 percent higher if all establishments hired blacks with the same probabilities as the largest ones.

${ }^{33}$ Multiplying differences in the frequencies of white and black new hires in each size category by the wage differentials for blacks in that category (relative to the largest) and summing these differences yields estimates of -.01 for all workers and -.02 for blacks. 
be driving the observed correlation between size and black employment. It is also possible that this correlation reflects heterogeneity in the relative quality (rather than quantity) of black applicants that firms receive, as noted above.

But the magnitude of the biases generated by such heterogeneity would have to be very large to generate the estimated effects presented above; and some of the omitted variables (such as differences in skill requirements) imply biases that go in the opposite direction of the findings presented here.

Therefore, it appears that establishment size per se has a large effect on the hiring of blacks, and that this is at least somewhat related to differences in the effects of EEO laws and regulations. As noted above, very small establishments are not even covered by EEO law; only larger establishments are monitored by the government through the filing of EEO-1 forms. Among firms that are covered and that file such forms, the larger ones are more visible to the public, and face greater risks of class action lawsuits or "bad press" from charges of racial bias if they hire too few blacks. ${ }^{34}$ This interpretation is perfectly consistent with the findings of Carrington, McCue, and Pierce (and also Smith and Welch), who find evidence that, as of the mid-1960s, blacks were overrepresented in small establishments, whereas now they are underrepresented.

That the self-reported use of Affirmative Action or the need to have "validated" hiring practices in the past does not help to account for the results presented here is somewhat troubling for this explanation. But it is quite likely that these dimensions of employer activity do not fully capture the effects of an establishment's size on its compliance efforts. ${ }^{35}$

Another possibility, not unrelated to the one just described, is that large firms use more formal hiring procedures than smaller ones, which leave less room for subjective and potentially discriminatory

\footnotetext{
${ }^{34}$ For instance, larger firms are also more likely to be federal contractors and to have undergone compliance reviews (Leonard 1985). For more discussion of these issues see Donohue and Siegelman (1991) and Bloch (1994).

${ }^{35}$ Even firms that are not federal contractors or that have never had to validate hiring practices are likely to make efforts to avoid discrimination if they fear the risk of lawsuits.
} 
judgments. The estimated effects of recruiting practices that are noted above are certainly consistent with these notions; a fuller set of these measures might indeed result in more evidence of such effects.

Overall, it seems quite likely that the relationship between establishment size and the tendency to hire blacks largely reflects much more pervasive discrimination in smaller establishments than in larger ones. Of course, these findings could reflect reverse discrimination against whites at the larger ones rather than (or in addition to) discrimination against blacks at the smaller ones. But this interpretation seems much less likely, since it would imply that whites face as much or more hiring discrimination on average as do blacks in the overall labor market, which conflicts with evidence from recent audit studies of employers (Fix and Struyk 1994). The fact that the ratio of hires to applicants in these data is well below one for blacks at even the largest firms (and therefore above one for nonblacks) also casts doubt on this alternative interpretation. ${ }^{36}$

The need for policy makers to devise remedies for employment discrimination at small establishments is thus strongly suggested by these results.

\footnotetext{
${ }^{36}$ While there might be "reverse discrimination" against whites in firms that practice Affirmative Action or in those with many black customers, these effects are already controlled for in the estimation above.
} 
APPENDIX TABLE A.1

Means of Independent Variables, by Establishment Size

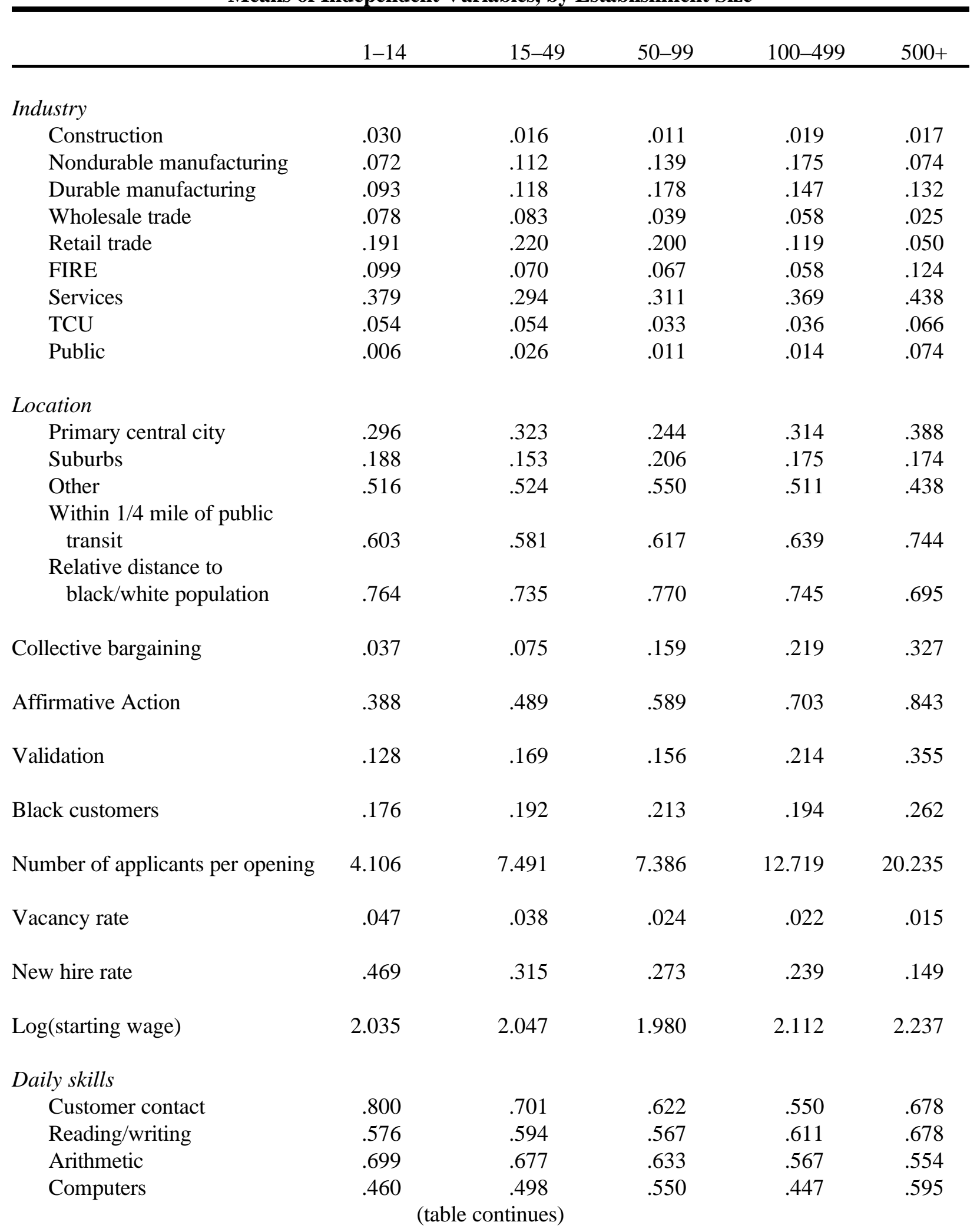


APPENDIX TABLE A.1, continued

\begin{tabular}{|c|c|c|c|c|c|}
\hline & $1-14$ & $15-49$ & 50-99 & $100-499$ & $500+$ \\
\hline \multicolumn{6}{|l|}{ Hiring requirements } \\
\hline High school diploma & .707 & .703 & .694 & .728 & .793 \\
\hline Specific experience & .585 & .617 & .528 & .622 & .661 \\
\hline Vocational training & .406 & .406 & .383 & .372 & .397 \\
\hline \multicolumn{6}{|l|}{ Recruitment methods } \\
\hline Informal referral & .516 & .390 & .378 & .386 & .355 \\
\hline Private employment agency & .024 & .038 & .111 & .053 & .050 \\
\hline Signs/walk-ins & .167 & .173 & .156 & .214 & .231 \\
\hline Newspaper ads & .206 & .335 & .256 & .239 & .240 \\
\hline $\begin{array}{l}\text { Public agencies, schools, } \\
\text { and unions }\end{array}$ & .087 & .064 & .100 & .108 & .124 \\
\hline Tests & .430 & .351 & .400 & .383 & .496 \\
\hline Probation period & .722 & .767 & .794 & .797 & .744 \\
\hline Hours of formal training & 21.322 & 18.981 & 28.889 & 29.019 & 38.901 \\
\hline
\end{tabular}

Note: Sample sizes are 335 for column one, 313 for column two, 180 for column three, 360 for column four, and 121 for column five. Sample sizes for "customers black" are smaller due to missing values. 


\section{References}

Anderson, Patricia, and Bruce Meyer. 1994. "The Extent and Consequences of Job Turnover.” Brookings Papers on Economic Activity, Microeconomics: 177-236.

Barron, John, Mark Berger, and Dan Black. 1994. "Employer Search, Training, and Vacancy Duration." Mimeo, Department of Economics, University of Kentucky.

Barron, John, John Bishop, and Mark Lowenstein. 1987. "Employer Size: The Implications for Search, Training, Capital Investment, Starting Wages, and Wage Growth.” Journal of Labor Economics 5 (January): 76-89.

Becker, Gary. 1971. The Economics of Discrimination. Chicago: University of Chicago Press.

Bloch, Farrell. 1994. Antidiscrimination Law and Minority Employment. Chicago: University of Chicago Press.

Bound, John, and Harry Holzer. 1993. "Industrial Shifts, Skill Levels and the Labor Market for White and Black Males." Review of Economics and Statistics 75 (August): 387-91.

Brown, Charles, and James Medoff. 1989. “The Employer Size-Wage Effect.” Journal of Political Economy 97 (October ): 1027-1059.

Brown, Charles, James Hamilton, and James Medoff. 1990. Employers Large and Small. Cambridge: Harvard University Press.

Carrington, William, Kristin McCue, and Brooks Pierce. 1995. "Using Establishment Size to Measure the Impact of Title VII and Affirmative Action." Mimeo, Department of Economics, Johns Hopkins University.

Chay, Kenneth. 1995. "The Impact of Federal Civil Rights Policy on Black Economic Progress: Evidence from the Equal Employment Opportunity Act of 1972." Mimeo, Department of Economics, Princeton University.

Davis, Steven, John Haltiwanger, and Scott Schuh. 1995. Job Creation and Destruction. Cambridge: MIT Press.

Donohue, John, and Peter Siegelman. 1991. "The Changing Nature of Employment Discrimination Litigation.” Stanford Law Review 43 (May): 983-1033.

Fix, Michael, and Raymond Struyk, eds. 1994. Clear and Convincing Evidence: Measurement of Discrimination in America. Washington, D.C.:Urban Institute Press.

Freeman, Richard, and James Medoff. 1984. What Do Unions Do? New York: Basic Books.

Garen, John. 1985. "Worker Heterogeneity, Job Screening, and Firm Size.” Journal of Political Economy 93 (August): 715-39. 
Holzer, Harry. 1987. "Informal Job Search and Black Youth Unemployment." American Economic Review 77 (June): 446-52.

Holzer, Harry. 1994. "Job Vacancy Rates in the Firm: An Empirical Analysis.” Economica 61 (February): $17-36$.

Holzer, Harry. 1996. What Employers Want: Job Prospects for Less-Educated Workers. New York: Russell Sage Foundation.

Holzer, Harry, and Keith Ihlanfeldt. 1996a. "Customer Discrimination against Blacks and Hispanics." Mimeo, Georgia State University.

Holzer, Harry, and Keith Ihlanfeldt. 1996b. "Spatial Factors and the Employment of Blacks at the Firm Level." New England Economic Review (May):65-82.

Holzer, Harry, Lawrence Katz, and Alan Krueger. 1991. "Job Queues and Wages." Quarterly Journal of Economics 106 (August): 739-68.

Holzer, Harry, and David Neumark. 1996. "Are Affirmative Action Hires Less Qualified? Evidence from Employer-Employee Data on New Hires.” Department of Economics, Michigan State University.

Kain, John. 1968. "Housing Segregation, Negro Employment, and Metropolitan Decentralization." Quarterly Journal of Economics 82 (May): 175-97.

Leonard, Jonathan. 1990. "The Impact of Affirmative Action Regulation and Equal Opportunity Law on Black Employment.” Journal of Economic Perspectives 4 (October): 47-64.

Leonard, Jonathan. 1985. "Affirmative Action as Earnings Redistribution: The Targetting of Compliance Reviews." Journal of Labor Economics 3, no. 3 (July): 363-84.

Lynch, Lisa, and Sandra Black. 1995. "Beyond the Incidence of Training: Evidence from a National Employer's Survey.” Cambridge: NBER Working Paper No. 5231.

Moss, Philip, and Chris Tilly. 1995. "Soft Skills and Race: An Investigation of Black Men's Employment Problems.” New York: Russell Sage Foundation Working Paper.

Neal, Derek, and William Johnson.1996. "The Role of Pre-Market Factors in Black-White Wage Differences." Journal of Political Economy 104 (October): 869-95.

Smith, Finis, and James Welch. 1984. "Affirmative Action and Labor Markets." Journal of Labor Economics 2, no. 2 (April): 269-301. 